\title{
齜 蝕統計法に関する研究
}

特に進行状況について

第 4 編 歯牙個人評価值について

国本 朝 雄*

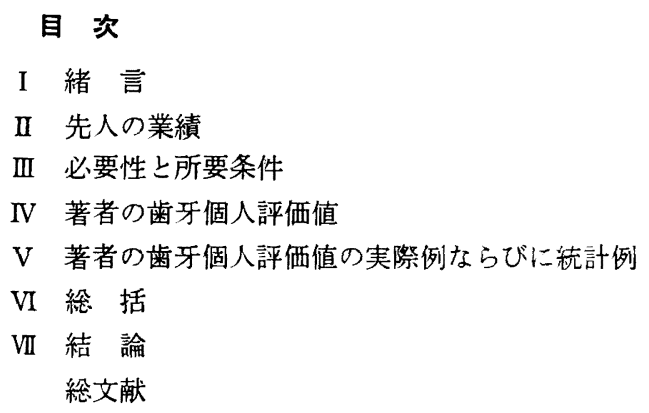

\section{I. 緒言}

従来一般に行なわれているところの個人口腔における 满触䍜患状況の表現形式は，いずれも発生的方面に限ら れたものであるが，近年次第にその標識を細かく採る傾 向があるといえよう。すなわち，1歯牙についても各歯 面の䍜患数とか, あるいは莓蝕起始点の数というように 次第に合理的になりつつあるが，それはあくまで䍜患状 況に限られるものであつて, 歯牙の健康度とかあるいは 能力等に関する表現は，このような計数的な発生的方面 のみでは到底合理的な評価はできないと思う。なぜなら ば，健康度あるいは，歯牙能力は唃強の進行的表現によ つて最もよく評価されるからである。

近来, 最も合理的なものとして次第に使用されつつあ る歯牙健康容量の如きも，その評価の根拠が単に便宜上 の採点法によるもので, 何等定量的なものでなく種々不 合理な点をもつており, 評価値としては合理的ではない 上うに思われる。

著者は歯牙個人評価值を次のように考えたい。すなわ

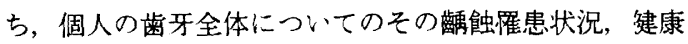
度，歯牙自身の能力等を評価する値である。

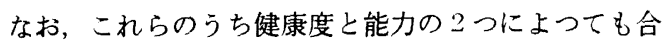

*東京㘹科大学口腔衙生学教室（主任故奥村鹤吉教授) 本論交の要旨は昭和 30 年 10 月第 130 回東垿学会に扣 いて発表した。昭和 36 年 6 月 14 日受付
理的な評価値とみることができよう。

しかして，著者は健康度を表わすものとして歯質健康 度, 能力 (咀嚼) については咀霞面能力, さらに両者を 結合して歯牙健能指数等を考案して，一応合理的な歯牙 個人評価値をうることができたと思う。

\section{II. 先人の業縗}

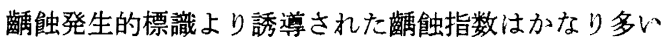

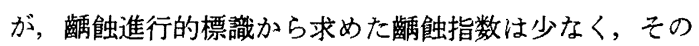

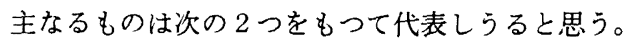

Charles F. Bodecker (1931) ${ }^{81}$ は，初めて人類硧触の 程度を測定する指数を称して, Modified Index of Dental Caries を発表した。その内訳は，i） Life caries index, i) Caries-susceptibility index, iii) Rerative caries index, iv) Relative caries-susceptibility index 等を揭げ て，採点法による唃触進行程度表現法に先鞭を付けた。

その要点を述べると, 全歯牙は 5 歯面をもち, 各歯面 上に触蝕起始点（可能点）があり, 永久歯 32 本で 160 点 をかぞえることができる。従つて 1 点宛 $0.625 \%$ の破損 部容積をもつといらことになり，1起始点に相当する欠 損は 1 点, 抜去歯は 3 点, 冠は 2 点, 架工支台歯 2 点等 の如き採点法によつて計算されるものである。

T. W. Clune (1944) ${ }^{91}$ が, 6 歳臼歯の状態を表現す る指数として, Dental health capacity と DMF index とを発表した。

岡本 ${ }^{10}$ はこれを健康容量または健康能力と訳しており A. L. Jensen は機能容量の意味に使用している。その 要点を述べると，6歳臼菌の欠損を歯面によつて採点し たもので

i ）歯面健康なるもの一 2 点

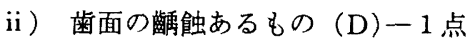

iii） 1 歯面の充埃あるもの (F) - 1.5 点

iv）残根, 啔失菌 $(\mathrm{M})-0$ 点

以上 6 歳臼菌 4 本 40 点満点で $100 \% ， 4$ 歯合計する。ま 
た, DMF index $=100 \%$ 一健康容量（\%)

以上は近年次第に使用されるようになつてきた。

\section{III. 齿牙個人評価值の必要性と所要条件}

口腔衛生の普及に伴つて, 個人の口腔の健康度ならび にこれに由来する歯牙能力の判定評価は, 当然吾人の重 要な仕事の1つといえよう。しかも，近来わが国でも次 第にかかる評価值が使用されはじめた傾向があるのは, 他国に比して遅すぎた感がある。特に歯牙の能力に関し ては将来性のある研究分野上して残されているが，これ は個人口腔の評価標識上なるわけで, 補填統計とも関連 し，先にのべた歯牙機能統計の 重要な事項である上思 5.

次に評価値として具備すべき条件を考えてみると，

i ）百分率で表現しうること。

ii）統計単位となりうること。

iii） 口腔つ 全歯牙にわたつて意味うけられているこ 上。これは萠出歯数立基脴とするものであつて, 1 歯宛 平均值となる。

iv）难患状況, 健康度, 能力は定量的な根拠をもつ こと。すなわち, 個人口腔は発生的に評価するより, 定 量的による方がはるかに合理的であると思う。

v ）歯牙の健康度と咀嚼能力とは, 咀嚼面において のみ比例することに留意されていらねばならない。すな わち, 咀喛機能は咀嚼面においてのみ発揮しうる故, 他 の歯面における鋆蝕欠損はほとんど影響しないとみなし てよい。特にこの点に関して現在までの評価値は，全く 無視しているようである。

vi）龋蝕ならびに 健康度は䶪蝕量によつて 評価さる ベきである。一般に進行程度を表現するのに階級度数を 使用しているが，むしろこれは䓰蝕量率によるべきで， 階級度数は参考上して付記する方がよいように思う。

以上のうち特に iv)一vi）が重要な意義をもつもので ある。

以上の条件によつて先に述べた先人の業績を批判して みると、

i ）採点の根拠が単に便宜的, 主観的であつて, 合 理的客観的ではない。

ii）各歯面における進行程度を無視して，一律に採 点している点不合理である。なぜならば 1 歯面において も $\mathrm{C}_{0}-\mathrm{C}_{2}$ にわたつて, 硧蝕量率は $0 \%$ - 27\%にわたる ものであるからである。

iii）歯牙健康度と能力とは必らすしも比例的に一致し ないということを無視している。なぜならば, 能力の減
退は咀嚼面欠損によつてのみ起るものであつて, 他の歯 面のそれによつてはほとんど影響されないからである。

iv）充填による能力減退を意味する場合は, 咀嚼面 においてのみ有意であることを無視している。こ机は ii）上同様であるといえよう。

以上からして前記の 2 つの評価法はよい方法上はいえ ないように思われる。

\section{IV. 著者の歯牙個人評価值}

先に述べた所要条件に通ずるものであつて，歯牙健康 度を表わすものとして，1 1 1 1 歯宛平均健康質量率を採 用して歯質健康度と称し，次に歯牙の能力を表わすもの 上して, 1 人 1 歯宛平均咀嚼面能力を咀嚼面能力, さら に両者を合して歯牙健康能指数と称することとした。

1. 歯質健康度

歯牙の健康度とは, 歯牙の生物学的健康状態であるが, この場合は歯質の䠛蝕に罹患していない部分，すなわち 健康歯質の量（容積）を採つて 健康度測定の 基準こし た。これはもちろん臨床的に観察した結果から求められ るものであつて, 歯質損失状況と反比例の状態にあり, 従つて補塡量とも反比例し, 機能統計的には咀獣面に㧍 いてのみ正比例の関係にある。

求め方についてしるすと, 次の如くである。

i) 直接測定法

第 1,2 編にのベた硧蝕量の求め方と同様に, 直接的に 容積を測定する方法と,齳窩の広さ,深さより間接的に推 定する方法によつて唃蝕量をまず測定し，これから敬蝕 量率を求め, 次に, 歯質健康度 $=100 \%$ 一硧蝕量率に上 る。もちろん衰失歯の場合は $0 \%$ である。

この方法は時間的にみて, 少数精密評価の場合におこ なう方法である。

特に龉強進行速度を同一人について測定し，時間的に みた健康度の推移を観察する場合に必要な方法といえよ う。

ii ) 間接推定法

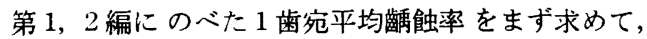
次に 1 人 1 歯宛平均健康質量率 $=100 \% 1$ 人 1 歯宛啐蝕 量率によつて求める。

2. 咀獣面能力

第 3 編にてのべたが，今回の評価値は 1 人 1 歯宛平均 咀嚼面能力に相当するものである。特に充填による減点 は不台理であるが, 健康度における減点ならばよい上考 える。この点注意すべきであろう。

3. 歯牙健能指数 
1，2 を合わせて 個人歯牙健康能力指数を求めるので あるが、従来使用されているものと区別するためにこの ように呼称することとした。

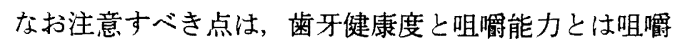
面に関してのみ比例的であるが，他の部分ではほ上んど 関係のないことである。

次のように両者を平均して求めるが，その意味する上 ころは全菌牙に平均した 1 歯宛平均歯質健康咀㗂面能力 指数々いうことになろう。

歯牙健能指数 $=\frac{\text { 歯質健康度十咀㗂面能力 }}{2}$ とする。

\section{V. 著者の個人歯牙評価値の実際例}

1）歯質健康度

i) 直接测定法（図 1)

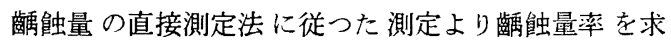
図 1 個人齿牙評価例

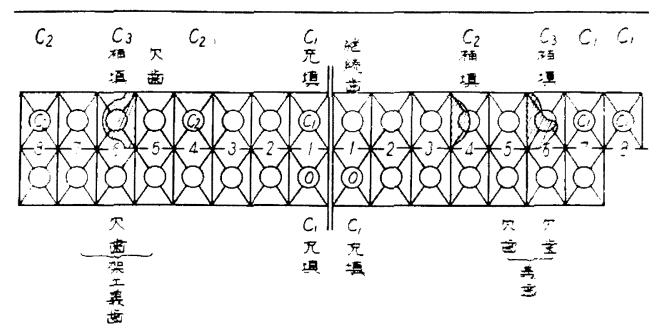

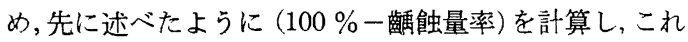
らより1㐘宛平均值を求むればよい。この方法は少数例 を精密に調査し，時間的経過を観察する場合に適する。

実測值は次のようである。ただし，補继歯は実際に計 測しえない故，先に述べた限界值から計算した中央值を 使用した。従つて，実測したものは

$\lfloor 7=5.34 \%,\lfloor 8=7.2 \%, \quad 4\rfloor=22.41 \%, \quad \overline{8}\rceil=13.45 \%$ で, 推定值としては $\frac{1}{1} \mid$ 万がそれぞれ $\mathrm{C}_{1}$ で $3 \%$ \% 6 |16 がそれぞれ $\mathrm{C}_{3}$ で $63.5 \%, \frac{5}{6} \mid \frac{1}{56}$ は $\mathrm{C}_{\mathrm{M}}$ それぞれ $100 \%$ これらを合計すると $647.90 \%$ 。これを 1 歯宛平均した 敬蝕量率は $20.9 \%$ となり，100\%-20.9\%=79.1\%。こ れが 1 歯宛平均歯質健康度である。

ii）間接推定法

階級 階級幅(歯質健康度) 階級度数 階級度数比率

$\begin{array}{lccc}\mathrm{C}_{0} & 100 \% & 17 & 0.5483 \\ \mathrm{C}_{1} & {[100-94] \%} & 5 & 0.1612 \\ \mathrm{C}_{2} & {[94-73] \%} & 3 & 0.0967 \\ \mathrm{C}_{3} & {[73-0] \%} & 3 & 0.0967 \\ \mathrm{C}_{\mathrm{M}} & 0 \% & 3 & 0.0967\end{array}$

平均歯質健康度 $=0.5483 \times 100 \%+0.1612\left(\frac{100+94}{2}\right) \%$

$$
\begin{aligned}
& +0.0967\left(\frac{94-73}{2}\right) \%+0.0967\left(\frac{73+0}{2}\right) \% \\
= & 54.83 \%+15.6364 \%+8.0744 \%+3.5295 \% \\
= & 82.0703 \%
\end{aligned}
$$

標準偏差 $=\sqrt{\left\{0.5483(100-82.07)^{2}+0.1612\right.}$

$$
\begin{aligned}
& \left(\frac{100+94}{2}-82.07\right)^{2}+0.0967\left(\frac{94-73}{2}-82.07\right)^{2} \\
& \left.+0.0967\left(82.07-\frac{73+0}{2}\right)^{2}\right\}
\end{aligned}
$$

$=\sqrt{(176.2701+35.9322+0.1977+200.8096)}$

$=20.32$

以上の如き直接法と間接法との差はやむを得ないもの と思う。

2. 咀嚼面能力

i) 直接法

咀嚼欠損面の 測定法は第 1 編に述べたようにおこな い, これを $100 \%$ から減じた残りが咀緦残存面であり, 全咀嚼面との比が咀嚼面能力である。

実測値としては,

$\lfloor 7=75 \%,\lfloor 8=96.53 \%, \underline{4}\rfloor=56.04 \%, \underline{8}\rfloor=52.65 \%$ $\underline{5}=0 \%$

この場合, 補填歯は $100 \%$ とした。従つて上記の他は $100 \%$ となるわけで，これらを平均した結果 $93.56 \%$ が えられた。これがすなわち，1歯宛咀緭面能力である。

\section{ii ）間接法}

$\begin{array}{cccc}\text { 階級 } & \text { 階 級 限 界 } & \text { 階級度数 } & \text { 階級度数比率 } \\ \mathrm{C}_{0} & 100 \% & 26 & 0.8387 \\ \mathrm{C}_{1} & {[100-95] \%} & 2 & 0.0645 \\ \mathrm{C}_{2} & {[95-0] \%} & 2 & 0.0645 \\ \mathrm{C}_{3} & 0 \% & 0 & 0 \\ \mathrm{C}_{\mathrm{M}} & 0 \% & 1 & 0.0322\end{array}$

平均咀嚼能力 $=0.8387 \times 100 \%+0.0645\left(\frac{100+95}{2}\right) \%$

$$
\begin{aligned}
& +0.0645\left(\frac{95+0}{2}\right) \% \\
= & 83.87 \%+7.2637+3.1065 \\
= & 94.2402 \%
\end{aligned}
$$

標準偏差 $=\sqrt{\left\{0.8387(100-94.24)^{2}\right.}$

$$
\begin{aligned}
& +0.0645\left(\frac{100+95}{2}-94.24\right)^{2} \\
& \left.+0.0645\left(94.24-\frac{95+0}{2}\right)^{2}\right\} \\
& =\sqrt{(27.8743+0.6854+140.9084)}
\end{aligned}
$$$$
=13.01
$$ 
iii) 歯牙健能指数

実測値を使用すると，

$$
\begin{aligned}
\text { 歯牙健能指数 } & =\frac{\text { 歯質健康度 }+ \text { 咀鲫面能力 }}{2} \\
& =\frac{79.10+93.56}{2} \% \\
& =86.33 \% \\
& \text { VI. 総 括 }
\end{aligned}
$$

歯牙個人評価值は個人における歯牙の健康度と咀嚼能 力（呾嚼面能力）を評価する数值であつて，近来次第に 使用されつつあるが，何れも主観的，便宜的な採点評価 を為しているために，不合理な点を感じないわけにはい かない。例えば, 最も有用と見なされている歯牙健康能 力においても，

○採点の根拠が便宜的であつて合理的でない。

○各歯面における蹫蝳進行状況在無視して一律に採点 している点不合理である。

○歯牙健康度と歯牙の能力は咀夁面においてのみ比例 し，他歯面ではほとんど無関係である点を無視してい る。

○充塡による能力減退は咀嚼面においてのみ有意であ ることを無視している。

等を考えると,一見甚だ便利で合理的に思われるけれど， 歯牙健康度ならびに咀嚼能力を客観的, 合理的に評価し ているとは思われない。

かかる評価值の所要条件としては，百分率で表わしう るもので全歯牙に平均しうるものであり, 健康度, 能力 はともに定量的な根拠をもつていることを必要とし，健 康度々咀嚼能力とは咀嚼面においてのみ比例的であるこ とに留意されなければならない等を掲げうると思う。

著者は如上のような所要条件にかなうものとして，す でに第 $1 ， 2$ 編においてのべたもののうちから次の $2 つ$

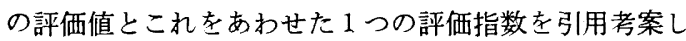
た。
a) 歯質健康度（1 人 1 歯宛平均健康質量率）
b) 咀嚼面能力（1人 1 蒾宛平均咀嚼面能力）
c) 歯牙健能指数 $\left(=\frac{\text { 歯質健康度 }+ \text { 咀嚼面能力 }}{2}\right)$

しかして a)，b）は直接測定法と間接測定法こ 2 通り の計算法があり，これらによると個人歯牙の健康度ある いは咀嚼能力を客観的，合理的に評俇しうるものと信ず る。

\section{VII. 結 論}

個人歯牙評価值について従来のもの在検討し，その欠 点を除きより合理的と思う新たな評価值を考案した。

i ）個人歯牙評価值の所要条件としては，百分率で あらわし，1歯宛平均を意味することができ，健康度， 能力はともに定量的な根拠をもち，かつ咀嚼面において のみ比例的であることに留意されていなければならな い。

ii ）従来の評価值は，採点の根拠が便宜的で合理的 でなく，各歯面における唃蝕進行状況を無視して一律に 採点している点, あるい住健康度と能力は咀嚼面におい てのみ,比例的であることを無視しており，かつ充壃によ る能力減退を咀嚼面以外の歯面にまでおよぼしている等 の諸点でよい評価値とは思えない。

iii）著者は，如上のような所要条件にかなうものと して，先に述べた第 $1 ， 2$ 編のうちより歯牙健康度をあ らわすものとして 1 人 1 歯宛平均健康質量率を採つて歯 質健康度とし, 咀嚼能力の程度を示すものとしては, 1 人歯宛平均咀嚼面能力を採つて咀緭面能力とした。

iv）さらに，1評価値で両者を兼ねるものとして， 歯牙健能指数 $=\frac{\text { 歯質健康度 }+ \text { 咀嚼面能力 }}{2}$

を考案した。

稿を終るにのぞみ第 1，2編で協力されたる故友藤原 隆蔵君の霊前に之をそなえ，本研究の協力者として君を 推された主任教授米沢和一博士に敬意を表し, 種々御援 助を頂いた同教室助手田辺明氏に感謝す。(昭和32年記) 向扣本稿の発表を溪揚された東京蔽科大学衛生学教室 竹内光春教授に深謝す。

\section{主なる引用文献}

1）国本朝雄：口腔衙生学会雑誌，6:4（1956）

2）竹内光春：臨床歯科学報, $4: 30$ (1949)

3) 石原寿郎：菡界展望, $10: 183$ (1953)

4）矢崎正方 : 速科学報, $34: 103$ (1929)

5）神山 稳：墦科学報, $46: 725$ (1941)

6）神山 稔：揌科公報, $2: 3$ (1941)

7) Manly, R. S. : J. D. Res., $30: 874$ (1951)

8) Charles F. Bodecker: J. Am. Dent. Assoc., $26: 1453$ (1939)

9) T. W. Clune: J. Am. Dent. Assoc., $32: 1262$ (1945)

10) 岡本清綑 : 新口腔衛生学(個人口腔衛生) (1960). 


\title{
A STUDY ON STATISTICS OF DENTAL CARIES
}

\author{
$\mathrm{By}$ \\ Asao KUNIMOTO \\ Department of Oral Hygiene, Tokyo Dental College \\ (Chief : Prof. T. Okumura)
}

This study is a continuation of "A Study on Statistics of Dental Caries" published in Japan Journal of Oral Hygiene, No. 1, Vol. 6, 1956.

Chapter I.

On the aggravation grade of caries, and the defective stage of dental substance, with special reference to "a scale for measuring the aggravation".

We propose to use the following scale in order to measure the aggravation degree of caries. This scale has the advantage of being objective and quantitative, as compared with the usual classification which is subjective and qualitative.

i) volume of caries-capacity of defect in dental substance after the removal of soft dentine.

ii) carious surface, especially defect of masticating surface-defect of the surface of a tooth caused by caries, especially of the masticating surface.

iii) volume rate of caries $=$ volume of caries/total volume of dental substance $\mathrm{C}_{1}=(0-6) \%, \mathrm{C}_{2}=(6-27)$ $\%, \mathrm{C}_{3}=(27-100) \%, \mathrm{C}_{\mathrm{M}}=100 \%$

iv) rate of masticating surface defect $=$ defect of masticating surface/total masticating surface $\mathrm{C}_{1}=(0-$ 5) $\%, \mathrm{C}_{2}=(5-100) \%, \mathrm{C}_{3}=100 \%, \mathrm{C}_{\mathrm{M}}=100 \%$.

The author considers these characteristics will serve as the basis for the aggravation statistics of caries, statistics of dental ability, or evaluation of individual dental status.

Chapter II.

Statistics of caries aggravation

In Chapter I, we have pointed out the defects of usual statistics of caries aggravation, and having studied a method for ameliorating them, we have proposed a statistical measurement of caries aggravation.

In this Chapter we also derive diverse statistics from the proposed characteristics. As far as we know, no study in this field has yet been made; and this study is the result of the original idea of the author.

i) The following characteristics are used as the basis for measuring the aggravation grade of caries:

"volume of caries",

"carious surface",

"defect of masticating surface".

ii) From these fundamental characteristics, eight following statistics are derived: volume rate of caries, defect rate of surface, remaining rate of masticating surface, aggravation velocity of caries, aggravation rate of caries, volume rate of healthy substance, ability of masticating surface, index of dental health and ability.

iii) These characteristics are calculating for all defective teeth, total teeth, by location and by person. Morever, we have also derived many statistics from them. The author belives these statistics are sufficient for the study of the process of caries.

iv) They will also serve as a convenient basis for comparing the resistibility of dentine against caries, a problem much discussed lately.

Chapter III.

Statistics of dental function, especially of the "ability of masticating surface"

We have studied the statistics of masticating ability, which is the most important part of dental statistics, and have also studied the ability of masticating surface which plays a fundamental rôle.

We have obtained the following conclusions:

i) It has become possible to classify the studies on masticating function into two groups, i. e., the one on ability, the other on efficiency. It seems to us the statistics on ability are less than those on efficiency. This is perhaps due to the difficulty and complexity of measuring.

ii) As the most important results on masticating ability, we may enumerate the calculation of contact point and surface by Dr. Yazaki, measurment of transparency of masticated wax plate by Dr. Manly, but all these studies on the decrease of masticating ability concern only with the change cause by a dental defect, and, as far as the author knows, no study has yet been made on the decreasing of masticating ability in the course of caries aggravation.

iii) In order to study masticating ability; we have to consider some fundamental conditions such as the width of masticating surface, or influence of caries, etc. These factors are taken into account by calculating the "ability of masticating surface".

iv) The "ability of masticating surface" is measured by the defect rate of masticating surface, 
calculated directly by measuring the defect of masticating surface by means of a sheet wax.

v) Another method for measuring the "ability of masticating surface" is an indirect one, which gives a statistical scale based on the frequency distribution of aggravation grade of caries and also the defect rate of masticating surface corresponding to each grade.

Grade $\quad \mathrm{Co} \quad \mathrm{C}_{1} \quad \mathrm{C}_{2} \quad \mathrm{C}_{3} \quad \mathrm{C}_{\mathrm{M}}$ limit of grade $100 \% \quad(100-5) \% \quad(5-0) \% \quad 0 \% \quad 0 \%$

vi) The measurement and the statistical analysis of the "ability of masticating surface" will form a basis for the development of a new field, i.e., the study of the influence of caries on the "efficiency of mastication" and of the statistics of filling and prosthetic appliance.

Chapter IV.

Evaluation of individual dental status

We examinated the usual evaluation method of individual dental status, and propose to use a new and more rational evaluation method free from their defects.

i) The evaluation of individual dental status is to be preferably expressed in percentage, so as to give the average for each tooth, and thus enabling to describe quantitatively dental health and ability.
But for the masticating surface the evaluation is given by a proportion.

ii) The usual evaluation are based on an arbitrary scaling and have no rational meaning. They neither distinguish between different stages of caries on each dental surface, nor take into account of the fact that the health and the ability are not necessarily proportionate to each other except for the masticating surface. Moreover, they athibute the influence of filling on the decrease of masticating ability even to other surfaces than the masticating surface. For these reasons, the author considers them unsatisfactory.

iii) The author proposes to use "dental health grade" expressed by the average healthy volume by person, defined in Chap. II and III. This grade satisfies, considers the author, the above mentioned conditions and represent well the grade of dental health.

The author proposes also to use the " ability of masticating surface" expressed by the average ability of masticating surface by person, in order to measure the masticating ability.

iv) As an unified value of these two values, we define "index of dental health and ability"

$=1 / 2$ (dental health grade+ability of masticating surface).

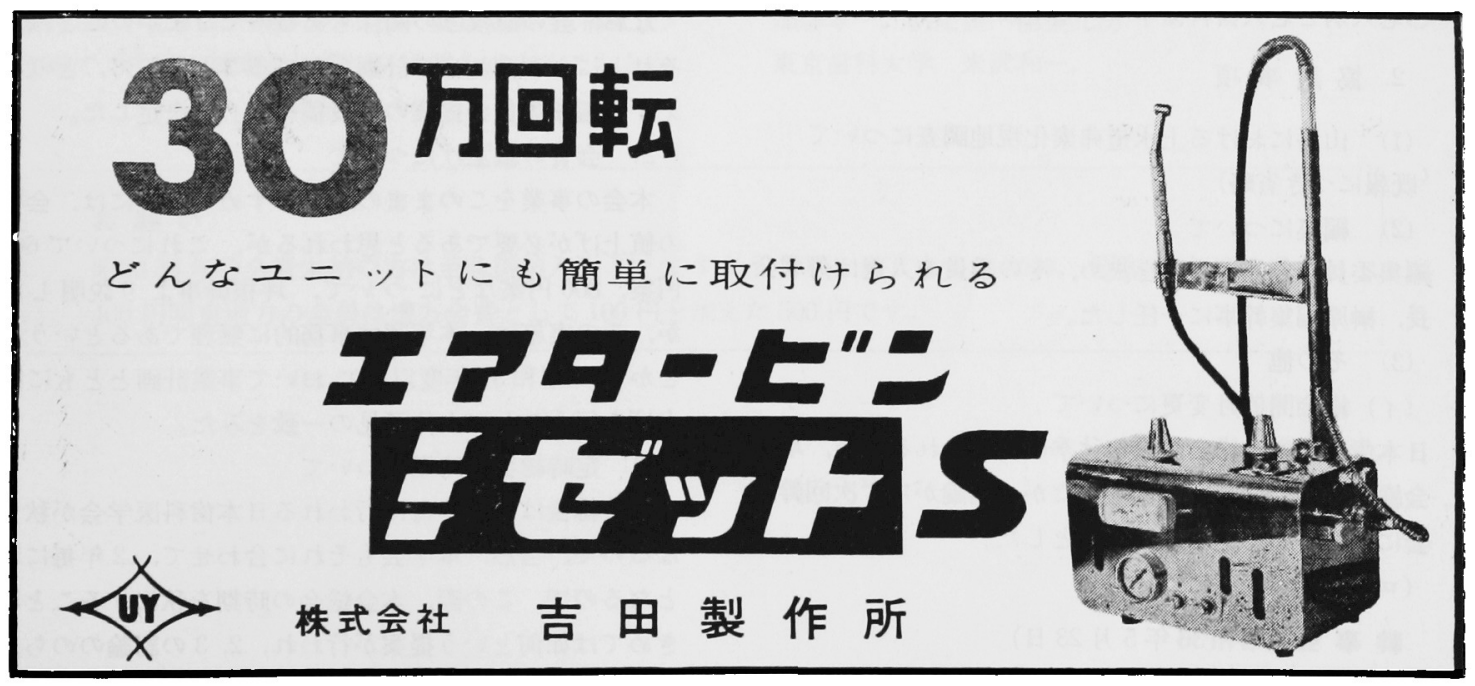

